\title{
The role of quantitative genetic studies in animal physiological ecology
}

\author{
El rol de los estudios genético-cuantitativos en ecología fisiológica animal \\ PAULINA ARTACHO ${ }^{1}$, LUIS E. CASTAÑEDA ${ }^{1} \&$ ROBERTO F. NESPOLO ${ }^{1 *}$ \\ ${ }^{1}$ Instituto de Ecología y Evolución, Facultad de Ciencias, Universidad Austral de Chile, \\ Casilla 567, Valdivia, Chile; \\ * Corresponding author: robertonespolo@uach.cl
}

\begin{abstract}
Evolutionary physiology is a new discipline with roots in comparative physiology. One major change in the emergence of this discipline was an explicit new focus on viewing organisms as the evolutionary products of natural selection. The shift in research emphasis from comparative physiology to evolutionary physiology has resulted in physiological traits becoming important elements in broad research programs of evolution and ecology. Evolutionary quantitative genetics is a theory-based biological discipline that has developed the quantitative tools to test explicit evolutionary hypotheses. The role of quantitative genetics has been paramount, in studying the microevolution of morphology, behavior and life history, but not comparative physiology. As a consequence, little basic information is known such as additive genetic variation of physiological traits and the magnitude of genetically based trade-offs (i.e., genetic correlations) with other traits. Here we explore possible causes for such gap, which we believe are related with the inconsistency of what we call physiological traits across taxonomic and organizational divisions, combined with logistical problems of pedigree-based analyses in complex traits.
\end{abstract}

Key words: evolutionary physiology, heritability, directional selection differential, response to selection, fitness.

\section{RESUMEN}

La fisiología evolutiva es una nueva disciplina con raíces en la fisiología comparada. Uno de los principales cambios introducidos con esta disciplina es un enfoque donde los organismos son analizados en forma explícita como el producto de selección natural. Este cambio de énfasis desde fisiología comparada a fisiología evolutiva ha resultado en que los rasgos fisiológicos son elementos importantes en el programa de investigación de la evolución y la ecología. La genética cuantitativa evolutiva es una disciplina biológica con bases teóricas que ha desarrollado las herramientas cuantitativas para someter a prueba hipótesis evolutivas en forma explícita. El rol de la genética cuantitativa ha sido notable en el estudio de la microevolución de la morfología, comportamiento e historia de vida, pero no en fisiología comparada. Como consecuencia, existe escasa información básica sobre variación genética aditiva de rasgos fisiológicos y posibles compromisos genéticos (i.e., correlaciones genéticas) que puedan tener estos con otros rasgos. En este comentario exploramos las posibles causas de este vacío, las cuales creemos están relacionadas con la inconsistencia de lo que llamamos rasgos fisiológicos entre las divisiones taxonómicas y organizacionales, a los que se agregan problemas logísticos inherentes a los análisis genealógicos en rasgos complejos.

Palabras clave: fisiología evolutiva, heredabilidad, diferencial de selección direccional, respuesta a la selección, adecuación biológica.

\section{INTRODUCTION}

Biology has always differed from chemistry and physics in the sense that fundamental theories and laws that aim to predict every phenomenon (as in the later) are unlikely to exist (Murray 2001). There are many reasons for that, most of them related with the fact that (1) what we call biological phenomena are complex frameworks of processes occuring across several levels of organization, and (2) there is an important amount of stochasticity or environmental "noise" added in each level of organization (Weber 2000). However, biological sciences are diverse; some fields are more formalized in terms of theories and laws than others. This is 
probably due to historical, as well as practical reasons. Disciplines that are mostly experimental are less theoretical and are essentially grounded on empirical patterns and processes, an aspect that inspired their first researchers. We suggest comparative physiology is an example of this. The legacy of former comparative physiologists was a change in the way of thinking in order to consider organisms as the evolutionary product of natural selection (Schmidt-Nielsen 1995, McNab 2001). This aim was commonly addressed by the experimental comparison of physiological capacities between organisms from extreme environments.

Conversely, disciplines that arised from the interest to test explicit theoretical formulation such as the Darwinian evolutionary theory, have developed a more theoretical construct preceding empirical patterns. An example of the later is evolutionary quantitative genetics (Weber 2000). In times of interdisciplinary fusion and meta-analyses, the percolation of quantitative genetic procedures into comparative physiology would contribute greatly to the understanding of the explicit evolutionary causes and consequences of physiological traits. However, as we have searched in the literature, very few of these interdisciplinary approaches have been carried out so far. In this commentary we discuss the potential of evolutionary quantitative genetics to explore the underlying causes of physiological adaptation, the probable causes for its absence in comparative physiology, and possible solutions for such missing link.

\section{PHENOTYPE-BASED MICROEVOLUTION}

Evolutionary population geneticists such as Fisher (1930), Haldane (1932) or Wright (1932) addressed quantitatively the problem of selection and its evolutionary response in natural populations (i.e., microevolution). To solve their theoretical questions, they developed statistical methods for correlational and randomized experiments, that are now of common usage in biological sciences such as the analysis of variance, path analysis and related analytical procedures. The concept of fitness, as the reproductive potential of an individual $\left(R_{0}\right)$, is owed to Fisher $(1930$, see also Huey \& Berrigan 2001) who stated that the mean fitness of a population is equal to the additive genetic variance in relative fitness in this moment. This was called "the fundamental theorem of natural selection" (Ewens 1989), which is part of a more general expression, the Robertson-Price identity (Lynch \& Walsh 1998, also known as the "secondary theorem of natural selection", Caswell 1989) that equates the selection differential ( $\mathrm{S}=$ the difference in the mean value of the trait within generations) with the covariance of any trait and relative fitness ( $\mathrm{w}=\mathrm{R}_{0} /$ mean $\mathrm{R}$ ). The predictability of microevolution is encapsulated in the breeder's equation (Henderson 1984), which relates the response to selection in any trait $(\mathrm{R}=$ the difference in the mean value of the trait between generations) to the product of narrowsense heritability $\left(h^{2}=\right.$ the ratio between additive genetic variance and phenotypic variance) and $S$ (= the directional selection differential, see Fig. 1):

$\mathrm{R}=\mathrm{h}^{2} \mathrm{~S}$

For many traits that are interrelated through genetic correlations (i.e., correlations that persist across generations), Lande \& Arnold (1983) developed the multivariate selection theory that basically changed the equation (1) to a matrix equation. This new equation relates $\Delta \mathrm{z}$ (vector of the response to selection in a suit of traits which replaces $R$ ) with $G$ (the variance - covariance additive genetic matrix which replaces $h^{2}$ ) and $\beta$ (the directional selection gradient, which replaces $S$ ),

$\Delta \mathrm{z}=\mathrm{G} \beta$

This basic framework is a statistical approach to dissect genetic variation completely based on phenotypic measures and known pedigrees. Contrarily to what common knowledge regarding molecular genetics could lead to believe, there is no better procedure to determine the heritable variation in a trait in natural populations.

\section{THE CONFLICTING EVIDENCE: PHYSIOLOGICAL TRAITS}

Elements of the above equations as well as the use and statistical comparisons of whole 
equations have become very sophisticated after the income of computer-intensive likelihood and Monte Carlo methods (Boldman et al. 1995, Roff 1997, Steppan et al. 2002). A broad scope of organisms and types of traits are known from this perspective and hence, a great amount of predictable (micro) evolution is possible (Mousseau \& Roff 1987, Stirling et al. 2002). In fact, one of the general findings of evolutionary genetics is that genetic variation is abundant and the vast majority of traits respond to selection (Mousseau et al. 2000). However, the heritability of traits of interest to comparative physiologists has rarely been measured. Some progress has been made with bioenergetic traits of endotherm. Hayes \& O'Connor (1999) presented evidence supporting that the directional selection differential (S) could be high in thermoregulatory maximum metabolic rate (MMR) of a rodent. Dohm et al. (1996) and Dohm et al. (2001) showed that aerobic endurance, basal metabolic rate (BMR) and maximum metabolic rate (MMR) in Mus exhibit low $\mathrm{h}^{2}$ thus suggesting that these traits have low potential for response to selection. Besides, current estimates of heritabilities of metabolic rate in animals have low statistical power (Dohm et al. 2001, Nespolo et al. 2003, Bacigalupe et al. 2004). All this view may change soon as we are aware of at least two research programs currently in progress that are recording large and significant heritabilities of mammalian metabolic traits (Ksiazek et al., Nespolo et al. unpublished results; Sadowska et al. unpublished results).

The relevance of maternal effects, including the influence of parental care on the performance of young, formerly considered unimportant to adaptive evolution, have been reconsidered recently as determinant for the response to selection thanks to quantitative genetics (Mousseau \& Fox 1998). Several bioenergetic traits of mammals have presented high maternal-non additive genetic effects such as nonshivering thermogenesis (NST), sustained metabolic rate (SusMR), and mass of metabolically active organs (Nespolo et al. 2003, Bacigalupe et al. 2004). However, the adequate separation of maternal effects themselves from common environmental variance remains as an open question. On the other hand, the genetic correlation among bioenergetic traits and life history traits, that is, the components of the G- matrix that predict evolution of the integrated phenotype appear to be significantly different from zero in several cases (Nespolo, Bustamante, Bacigalupe \& Bozinovic unpublished results). Indirect analyses suggest that metabolism may be heritable in vertebrates because metabolic rates $\left(\mathrm{VO}_{2}\right)$ are repeatable (Hayes \& Chappell 1990, Speakman et al. 1994, Chappell et al. 1995, Berteaux et al. 1996, Hayes \& O'Connor 1999), because an underlying trait (e.g., hemoglobin polymorphism, brown adipose tissue) presents heritable variation (Snyder 1978, Chappell \& Snyder 1984, Lynch et al. 1988, Sorci et al. 1995), or because $\mathrm{VO}_{2}$ shows high broad-sense heritability (Garland et al. 1990). However, it should be noted that (1) high repeatability is not a guarantee of high heritability (Lessels \& Boag 1987, Dohm 2002), (2) underlying variables are expected to be more heritable than whole-organism traits because the latter are less influenced by environmental variance (Price \& Schluter 1991, Kruuk et al. 2003), and (3) broad-sense heritability includes maternal and common environmental effects, hence it is larger than $\mathrm{h}^{2}$ (Falconer \& Mackay 1997).

Clearly, the few quantitative genetic studies of physiological traits in natural populations of vertebrates have given mixed results that claim for more research with more statistical power. The scarcity of data about genetic variances and genetic correlations in physiological traits is paradoxical considering the long tradition in research of comparative physiologists. Almost in parallel, evolutionary quantitative geneticists have studied the dynamics of all components of equations (1) and (2) for life histories, morphology and behavior in birds (Barbraud 2000, Szekely et al. 2000, Merila et al. 2001), mammals (Boonstra \& Hochachka 1997, Kruuk et al. 2000, Thomas et al. 2000), reptiles (Janzen 1993, Shine \& Shetty 2001, Sinervo \& Zamudio 2001), amphibians (Van Buskirk \& Schmidt 2000, Watkins 2001, Uller et al. 2002), fishes (Reznick et al. 1997, Brooks \& Endler 2001, Karino \& Haijima 2001), insects (Fox et al. 1999, Begin \& Roff 2001, Stirling et al. 2002), mollusks (Parsonage \& Hughes 2002), crustaceans (Pfrender \& Lynch 2000) and bacteria (Travisano et al. 1995, Rileay et al. 2001). 


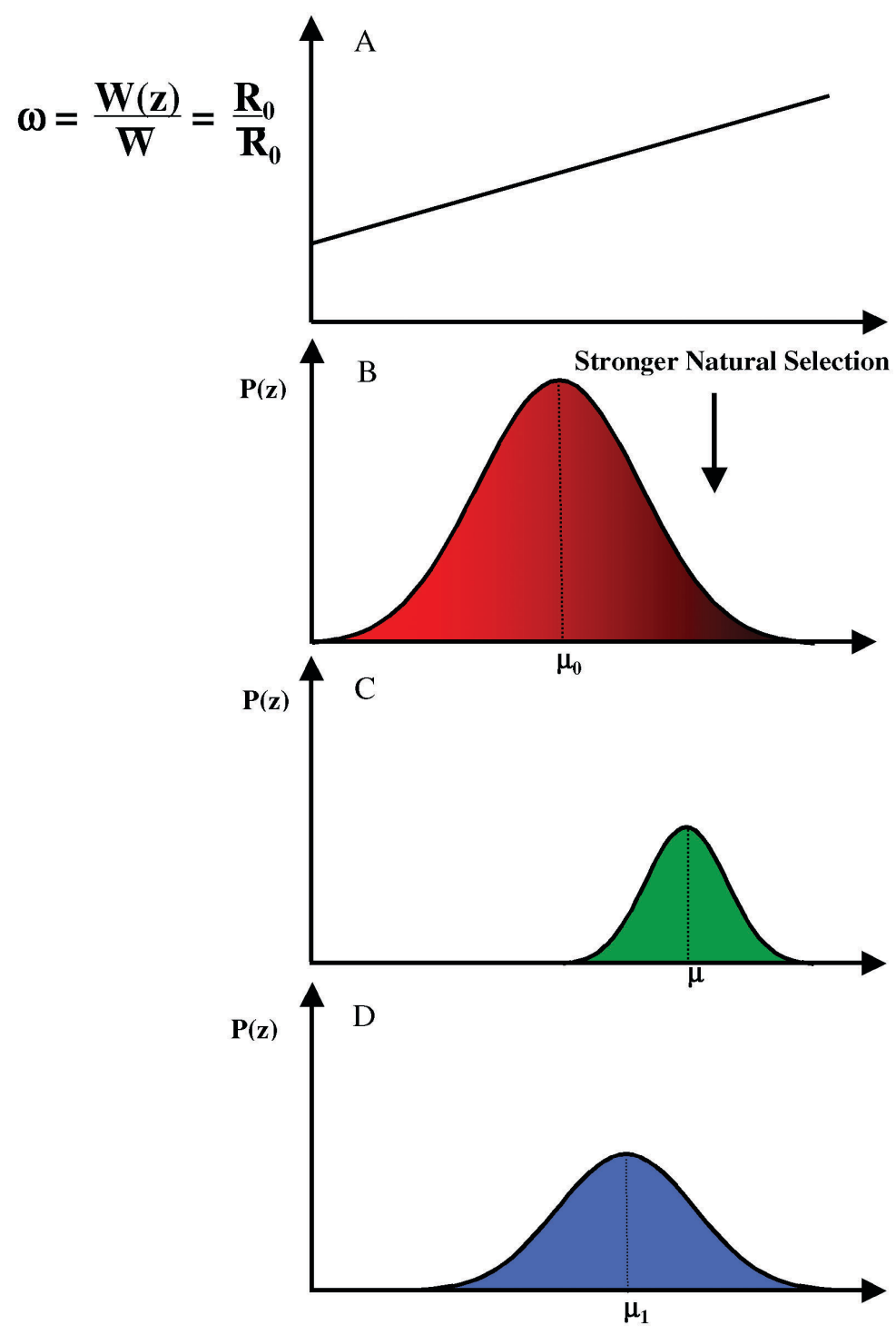

Physiological trait (z) (e.g., metabolic rate, evaporative water loss, sprint speed, endurance, sustained metabolic rate)

Fig. 1: Simplified diagram showing the analysis of the response to directional selection in a physiological trait, in a population. In this example, directional selection, evidenced by a positive correlation between relative fitness ( $\omega$ : the ratio between absolute and mean lifetime reproductive potential, $\mathrm{R}_{0}$, see Huey and Berrigan, 2001) and the mean fitness of the population, is acting on the right tail of a distribution of the trait (A and B). Red and green curves represent the distribution of the trait before and after selection within a generation, respectively (B and C). Shaded area in the red curve represent individuals with increased survival and/or differential reproduction, according to the fitness function. Similarly, $\mu_{\mathbf{o}}$ and $\mu$ represent the mean populational values before and after selection, respectively. The mean of the trait in the descendents of the selected individuals (i.e., between generations) is $\mu_{1}$. In this case, directional selection differential $\left(S=\mu-\mu_{0}\right)$ and response to selection $\left(\mathrm{R}=\mu_{1}-\mu_{\mathrm{o}}\right)$ in a hypotetical trait with narrow-sense heritability $\left(\mathrm{h}^{2}\right)$ of intermediate value (i.e., $h^{2} \sim 0.5$ ) is reflected in the fact that although selection is strong (the displacement of the green curve from the red curve), its evolutionary response is intermediate (the displacement of the blue curve from the red curve). The progresively shadowed (or the slope of the curve in A) area in the red curve represent, in a diagramatic form, the Robertson - Price identity: the selection diffe- 
There are obvious logistical problems related with developing quantitative genetic studies in comparative physiology. One major difficulty is to measure hundreds of individuals, as any pedigree-based design requires. Another problem relates to the fact that "physiological traits" are variables that are not functionally consistent across species. For some animals, many physiological traits (e.g., dessication resistance in insects, Hoffman, 2000) are functionally different from traits classified as "physiological" in other animals (e.g., oxygen carrying capacity by haemoglobin in mammals, Chappell \& Snyder 1984). Hence, heritability estimates of physiological traits may not be readily used to infer values in other physiological traits. Thus the scarcity of estimates and the breadth of variation within the physiological category make it difficult to reach firm conclusions regarding the range of heritabilities in this type of traits. These complications could be avoided, or at least ameliorated, by means of: (1) comparing estimates of different physiological traits obtained during the same experiments and measured to the same individuals, and (2) considering a common physiological trait in very different organisms. To sum up, much experimental work is needed to attain this objective, followed by an appropriate synthesis in the form of a meta-analysis to decide finally if physiology has the same microevolutionary potential than morphology, behavior and fitness.

\section{ACKNOWLEDGMENTS}

This commentary is dedicated to Mario Rosenmann, the first who talked about the Krogh principle as a way of thinking in the Chilean science. We thank T. Garland, R. Huey, D. Roff, D. Van Vleck, L.D. Bacigalupe, E.L. Rezende, and M.A. Lardies for discussion and motivation. This work was funded by DID grant S-200441 to R. Nespolo.

\section{LITERATURE CITED}

BACIGALUPE LD, RF NESPOLO, DM BUSTAMANTE \& F BOZINOVIC (2004) The quantitative genetics of sustained energy budget in a wild mouse. Evolution 58: 421-429.

BARBRAUD C (2000) Natural selection on body size traits in a long-lived bird, the snow petrel Pagodroma nivea. Journal of Evolutionary Biology 13: 81-88.

BEGIN M \& DA ROFF (2001) An analysis of G matrix variation in two closely related cricket species, Gryllus firmus and G. pennsylvanicus. Journal of Evolutionary Biology 14: 1-13.

BERTEAUX D, DW THOMAS, JM BERGERON \& $\mathrm{H}$ LAPIERRE (1996) Repeatability of daily field metabolic rate in female meadow voles (Microtus pennsylvanicus). Functional Ecology 10: 751-759.

BOLDMAN KG, LA KRIESE, LD VAN VLECK, CP VAN TASSELL, SD KACHMAN (1995) A manual for use of MTDFREML. A set of programs to obtain estimates of variances and covariances. First edition, Volume 1. United States Department of Agriculture, Agriculture of Research Service, Lincoln, Nebraska, USA. 250 pp.

BOONSTRA R \& WM HOCHACHKA (1997) Maternal effects and additive genetic inheritance in the collared lemming Dicrostonyx groenlandicus. Evolutionary Ecology 11: 169-182.

rential is equivalent to the covariance between relative fitness and the trait, $\mathrm{S}=\operatorname{Cov}(\omega, \mathrm{z})$. In other words, natural selection could be determined by regressing relative fitness with the value of the physiological trait in a sample of organisms from a population. See text for details.

Diagrama simplificado que muestra el análisis de la respuesta a la selección direccional en un rasgo fisiológico, en una población. En este ejemplo, la selección direccional, evidenciada por una correlación positiva entre la adecuación biológica relativa ( $\omega$ : razón entre el potencial reproductivo individual absoluto y el potencial reproductivo promedio, $\mathrm{R}_{0}$, ver Huey \& Berrigan 2001) y la adecuación biológica promedio de la población, está actuando en la cola derecha de la distribución del rasgo (A y B). La curva roja y verde representa la distribución del rasgo antes y después de la selección dentro de una generación, respectivamente (B y C). El área sombreada en la curva roja representa los individuos con la sobrevivencia y/o reproducción diferencial aumentada, de acuerdo a la función de la adecuación biológica. Similarmente, $\mu_{0}$ y $\mu$ representan los valores poblacionales promedio antes y después de la selección, respectivamente. La media del rasgo en los descendientes de los individuos seleccionados (i.e., entre generaciones) es $\mu_{1}$. En este caso, el diferencial de selección direccional $\left(S=\mu-\mu_{0}\right)$, y respuesta a la selección $\left(\mathrm{R}=\mu_{1}-\mu_{0}\right)$, en un rasgo hipotético con heredabilidad en sentido estricto $\left(h^{2}\right)$ de valores intermedios (i.e., $\left.h^{2} \sim 0.5\right)$, es reflejado en el hecho que aunque la selección es fuerte (el desplazamiento de la curva verde desde la curva roja), su respuesta evolutiva es intermedia (el desplazamiento de la curva azul de la curva roja). El área progresivamente sombreada (o la pendiente de la curva en A) en la curva roja representa, en forma diagramática, la identidad de Robertson-Price: el diferencial de selección es equivalente a la covarianza entre la adecuación biológica relativa y el rasgo, $\mathrm{S}=\operatorname{Cov}(\omega, \mathrm{z})$. En otras palabras, la selección natural podría ser determinada realizando una regresión entre la adecuación biológica relativa y el valor del rasgo fisiológico, en una muestra de organismos de la población. Ver texto para detalles. 
BROOKS R \& JA ENDLER (2001) Direct and indirect sexual selection and quantitative genetics of male traits in guppies (Poecilia reticulata). Evolution 55: 1002-1015.

CASWELL H (1989) Fitness and Evolutionary Demography. In: Sinauer (eds) Matrix population models:161-177. First edition. Sinauer Associates, Sunderland, Massachusetts, USA.

CHAPPELL M \& LRG SNYDER (1984) Biochemical and physiological correlates of deer mouse alpha-chain hemoglobin polymorphisms. Proceedings of the National Academy of Sciences USA 81: 5484-5488.

DOHM MR, JP HAYES \& T GARLAND (1996) Quantitative genetics of sprint running speed and swimming endurance in laboratory house mice (Mus domesticus). Evolution 50: 1688-1701.

DOHM MR, JP HAYES \& T GARLAND (2001) The quantitative genetics of maximal and basal rates of oxygen consumption in mice. Genetics 159: 267-277.

DOHM MR (2002) Repeatability estimates do not always set an upper limit to heritability. Functional Ecology 16: 273-280.

EWENS WJ (1989) An interpretation and proof of the fundamental theorem of natural selection. Theoretical Population Biology 36: 167-180.

FALCONER DS \& TFC MACKAY (1997) Introduction to quantitative genetics. Longman, Edinburgh, Scottland. $464 \mathrm{pp}$.

FISHER RA (1930) The genetical theory of natural selection. A complete variorum edition. Oxford University Press, New York, New York, USA. 318 pp.

FOX CW, ME CZESAK, TA MOUSSEAU \& DA ROFF (1999) The evolutionary genetics of an adaptive maternal effect: egg size plasticity in a seed beetle. Evolution 53: 52-560.

GARLAND T, AF BENNETT \& CB DANIELS (1990) Heritability of locomotor performance and its correlates in a natural population. Experientia 46: 530-533.

GARLAND T \& C ADOLPH (1994) Why not to do twospecies comparative studies: limitations on inferring adaptation. Physiological Zoology 67: 797-828.

HALDANE JBS (1932) The causes of evolution. Princeton University Press, Princeton, New Jersey, USA. 222 pp.

HAYES JP \& MA CHAPPELL (1990) Individual consistency of maximal oxygen consumption in deer mice. Functional Ecology 4: 495-503.

HAYES JP \& CSO O'CONNOR (1999) Natural selection on thermogenic capacity of high-altitude deer mice. Evolution 53: 1280-1287.

HENDERSON (1984) Application of linear models in animal breeding. University of Guelp, Guelp, Ontario, Canada. $462 \mathrm{pp}$.

HOFFMAN AA (2000) Laboratory and field heritabilities. Some lessons from Drosophila. In: Mousseau T, B Sinervo \& J Endler (eds) Adaptative genetic variation in the wild: 200-218. Oxford University Press, New York, New York, USA.

HUEY RB \& D BERRIGAN (2001) Temperature, demography, and ecthoterm fitness. American Naturalist 158: 204-210.

JANZEN FJ (1993) An experimental analysis of natural selection on body size of hatchling turtles. Ecology 74: 332-341.

KSIAZEK AM, M KONARZEWSKI \& IB LAPO (in press) Anatomic and energetic correlates of divergent selection for BMR in laboratory mice Physiological and Biochemical Zoology.
KARINO K \& Y HAIJIMA (2001) Heritability of male secondary sexual traits in feral guppies in Japan. Journal of Ethology 19: 33-37.

KRUUK LEB, TH CLUTTON-BROCK, J SLATE \& JM PEMBERTON (2000) Heritability of fitness in a wild mammal population. Proceedings of the National Academy of Sciences USA 97: 699-703.

KRUUK LEB, AJ MERILA \& BC SHELDON (2003) When environmental variation short-circuits natural selection. Trends in Ecology and Evolution 18: $207-$ 209.

LANDE R \& SJ ARNOLD (1983) The measurement of selection on correlated characters. Evolution 37 $1210-1226$

LESSELLS CM \& PT BOAG (1987) Unrepeatable repeatabilities: a common mistake. Auk 104: 116121

LYNCH CB, DS SULZBACH \& MS CONNOLLY (1988) Quantitative genetic analysis of temperature regulation in Mus domesticus. IV. Pleiotropy and genotype-by-environment interaction. American Naturalist 132: 521-537.

LYNCH M \& B WALSH (1998) Genetics and analysis of quantitative traits. Sinauer Associates, Sunderland, Massachusetts, USA. $136 \mathrm{pp}$

MCNAB BK (2002) The physiological ecology of vertebrates: a view from energetics. Cornell University Press, Ithaca, New York, USA. 576 pp.

MERILA J, LEB KRUUK \& BC SHELDON (2001) Cryptic evolution in a wild bird population. Nature 412: 76-79.

MOUSSEAU T \& C FOX (1998) Maternal effects as adaptations. Oxford University Press, New York, New York, USA. 375 pp.

MOUSSEAU TA \& DA ROFF (1987) Natural selection and the heritability of fitness components. Heredity 59: 181-197.

MOUSSEAU TA, B SINERVO \& J ENDLER (2000) Adaptive genetic variation in the wild. Oxford University Press, Oxford, United Kingdom. 265 pp.

MURRAY BG (2001) Are ecological and evolutionary theories scientific? Biological Reviews 76: 255289.

NESPOLO RF, M ARIM \& F BOZINOVIC (2003) Heritability of energetics in a wild mammal, the leaf-eared mouse (Phyllotis darwini). Evolution 57: $1679-1688$

PARSONAGE S \& J HUGHES (2002) Natural selection and the distribution of shell colour morphs in three species of Littoraria (Gastropoda : Littorinidae) in Moreton Bay, Queensland. Biological Journal of the Linnean Society 75: 219-232.

PFRENDER ME \& M LYNCH (2000) Quantitative genetic variation in Daphnia: temporal changes in genetic architecture. Evolution 54: 1502-1509.

PRICE TD \& D SCHLUTER (1991) On the low heritability of life history traits. Evolution 45: 853861.

REZNICK DN, FH SHAW, FH RODD \& RG SHAW (1997) Evaluation of the rate of evolution in natural populations of guppies (Poecilia reticulata). Science 275: 1934-1937.

RILEY MS, VS COOPER, RE LENSKI \& LJ FORNEY (2001) Rapid phenotypic change and diversification of a soil bacterium during 1000 generations of experimental evolution. Microbiology-UK 147: 995-1006

ROFF DA (1997) Evolutionary quantitative genetics. Chapman \& Hall, New York, New York, USA. 493 pp. 
SCHMIDT-NIELSEN, K (1998) The camel's nose. Island Press, Washington, District of Columbia, USA. 339 pp.

SHINE R \& S SHETTY (2001) The influence of natural selection and sexual selection on the tails of seasnakes (Laticauda colubrina). Biological Journal of the Linnean Society 74: 121-129.

SINERVO B \& K ZAMUDIO (2001) The evolution of alternative reproductive strategies: fitness differential, heritability, and genetic correlation between the sexes. Journal of Heredity 92: 198-205.

SNYDER LRG (1978) Genetics of hemoglobin in the deer mouse Peromyscus maniculatus part 2: multiple alleles at regulatory loci. Genetics 89: 531-550.

SORCI G, JG SWALLOW, T GARLAND \& J CLOBERT (1995) Quantitative genetics of locomotor speed and endurance in the lizard Lacerta vivipara. Physiological Zoology 68: 698-720.

SPEAKMAN JR, PA RACEY, A HAIM \& PI WEBB (1994) Inter and intraindividual variation in daily energy expenditure of the pouched mouse (Saccostomus campestris). Functional Ecology 8: 336-342.

STEPPAN SJ, PC PHILLIPS \& D HOULE (2002) Comparative quantitative genetics: evolution of the G matrix. Trends in Ecology and Evolution 17: 320327.

STIRLING DG, D REALE \& DA ROFF (2002) Selection, structure and the heritability of behaviour. Journal of Evolutionary Biology 15: 277-289.
SZEKELY T, JD REYNOLDS \& J FIGUEROLA (2000) Sexual size dimorphism in shorebirds, gulls, and alcids: the influence of sexual and natural selection. Evolution 54: 1404-1413.

THOMAS SC, JM PEMBERTON \& WG HILL (2000) Estimating variance components in natural populations using inferred relationships. Heredity 84: 427-436.

TRAVISANO M, JA MONGOLD, AF BENNETT \& RE LENSKI (1995) Experimental tests of the roles of adaptation, chance, and history in evolution. Science 267: 87-90.

ULLER T, M OLSSON \& GF STAHLBER (2002) Variation in heritability of tadpole growth: an experimental analysis. Heredity $88: 480-484$.

VAN BUSKIRK J \& BR SCHMIDT (2000) Predator induced phenotypic plasticity in larval newts: trade offs, selection, and variation in nature. Ecology 81 : 3009-3028.

WATKINS TB (2001) A quantitative genetic test of adaptive decoupling across metamorphosis for locomotor and life-history traits in the Pacific tree frog, Hyla regilla. Evolution 55: 1668-1677.

WEBER TP (2000) Biological objects, units of selection and character decomposition. Trends in Ecology and Evolution 15: 304-305.

WRIGHT S (1932) The roles of mutation, inbreeding, crossbreeding and selection in evolution. Proceedings of the Sixth International Congress in Genetics 1: 356-366. 